\title{
Electric Field Processing: Novel Perspectives on Allergenicity of Milk Proteins
}

\author{
Ricardo N. Pereira, ${ }^{\dagger}$ Rui M. Rodrigues, ${ }^{\dagger}$ R Óscar L. Ramos, ${ }^{\dagger}$ Ana C. Pinheiro, ${ }^{\dagger, \dagger}$ Joana T. Martins, ${ }^{\dagger}$ \\ José A. Teixeira, ${ }^{\dagger}$ and António A. Vicente*,† \\ ${ }^{\dagger}$ Centre of Biological Engineering (CEB), University of Minho, 4710-057 Braga, Portugal \\ ${ }^{\ddagger}$ Institute of Experimental and Technological Biology (iBET), Avenida da República, Quinta do Marquês, Estação Agronómica \\ Nacional, Apartado 12, 2781-901 Oeiras, Portugal
}

ABSTRACT: Milk proteins are being widely used in formulated foods as a result of their excellent technological, functional, and biological properties. However, the most representative proteins from casein and whey fractions are also recognized as major allergens and responsible for the prevalence of cow's milk protein allergy in childhood. Electroheating technologies based on thermal processing of food as a result of application of moderate electric fields, also known by ohmic heating $(\mathrm{OH})$ or Joule effect, are establishing a solid foothold in the food industry. Currently, the influence of $\mathrm{OH}$ on allergenic aspects of milk proteins is under debate but still undisclosed. The occurrence of electrical effects on the protein structure and its function has already been reported; thus, the impact of $\mathrm{OH}$ over allergenicity should not be overlooked. On the basis of these recent findings, it is then relevant to speculate about the impact of this emergent technology on the potential allergenicity of milk proteins.

KEYWORDS: ohmic heating, electric fields, $\beta$-lactoglobulin, antibodies, aggregation, gastrointestinal digestion

\section{INTRODUCTION}

Dairy products are part of everyday life, offering a great variety of food products. ${ }^{1-3}$ Whole milk and its fractionated ingredients are widely used in formulated foods, serving as functional and technological agents as a result of their unique nutritional and biological properties. Milk proteins are almost certainly one of the best and most extensively characterized food protein systems. They encompass not only a wellbalanced level of essential amino acids but also important biochemical and beneficial biological functions related to digestibility and immune system modulation. ${ }^{4}$ One outstanding example of this multifunctionality is the whey proteins, which are now at the top of the list of super molecules, taking place at an emerging frontier where nutrition and health are intertwined. ${ }^{5,6}$ However, milk proteins also have a "darker side" that limits worldwide consumption of dairy foods and that is related to their ability to elicit adverse immune responses and allergy. In fact, being typically extensively hydrolyzed throughout the digestive tract by gastrointestinal (GI) enzymes and brush border membrane, milk proteins release numerous amino acids that may exert beneficial properties but also adverse effects, such as those produced by epitopes involved in food allergies. ${ }^{7}$ Currently, cow's milk protein allergy (CMPA) is considered one the most prevalent food allergies in childhood, and it affects $1.9-4.9 \%$ of infants worldwide. ${ }^{8}$ Most children outgrow CMPA by the age of 4 years. However, a significant population can retain the allergy for life, where symptoms are much more severe, i.e., acute pulmonary and cardiovascular symptoms and anaphylactic shock. ${ }^{9}$ There is no suitable therapy available against CMPA, except milk avoidance, followed by a nutritionally adequate diet and immunotherapy treatments, in which tolerance can be triggered by the ingestion of the incriminated allergens. ${ }^{10}$ These preventive and therapeutic needs carry a number of drawbacks that can involve nutritional deficit outcomes, assessment of tolerance on a regular basis, or even a milk-free diet. Preventive measures are difficult to achieve because whey proteins, for example, are often present as an ingredient in many processed foods (e.g., meat), which are not labeled as containing it. Several types of food processing have been implicated in influencing allergenic properties of milk proteins, such as thermal processing (e.g., pasteurization, sterilization, and drying), fermentation, and enzymatic and acid hydrolysis. Among these processes, fermentation and hydrolysis have shown potential to reduce allergenicity to such an extent that symptoms are not elicited. ${ }^{11}$ However, they carry out changes in the sensory attributes and discrepancies in peptide composition, which affect the quality and value of the end product. Finding new food processing strategies to reduce allergenic properties of milk protein is still fundamental to decrease the incidence of CMPA. During the last few decades, technological advances and the need to address new consumer standards, much more focused on nutritional and functional and healthier aspects of food products, have driven the appearance of novel food processing technologies. ${ }^{12-14}$ Ohmic heating $(\mathrm{OH})$, an electroheating method of processing foods, is an outstanding example of this technological emergency in food processing, presenting now an interesting degree of maturity as a result of the fundamental and applied research developed over the last 20 years. Recently, several examples of the application of $\mathrm{OH}$ technology to develop an innovative dairy product have been reported. ${ }^{15-17}$ It is expected that, in a very short term, this technology, after assuring the required

Received: July 12, 2018

Revised: October 6, 2018

Accepted: October 8, 2018

Published: October 8, 2018 
Table 1. Chemical Properties and Allergenicity of Major Cow Milk Protein Allergens ${ }^{a}$

\begin{tabular}{|c|c|c|c|c|c|c|}
\hline milk protein & $\begin{array}{l}\text { IUIS allergen } \\
\text { nomenclature }\end{array}$ & $\begin{array}{l}\operatorname{maximum} \\
\text { amount } \\
(\mathrm{g} / \mathrm{L})\end{array}$ & $\begin{array}{c}\text { total } \\
(\%)\end{array}$ & $\begin{array}{l}\text { molecular } \\
\text { weight } \\
(\mathrm{kDa})\end{array}$ & $\begin{array}{l}\text { isoelectric } \\
\text { point }\end{array}$ & allergenicity feature \\
\hline whey fraction & & 5 & 20 & & & \\
\hline$\alpha-\mathrm{La}$ & Bos d 4 & 1.5 & 5 & 14.2 & 4.8 & $\begin{array}{l}>90 \% \text { of cow milk allergic patients showed IgE binding in crossed } \\
\text { radioimmunoelectrophoresis (CRIE); }>90 \% \text { showed IgE binding in } \\
\text { ELISA; } 8 \text { of } 19 \text { patients showed IgE binding to Bos d } 4 \text { peptides }\end{array}$ \\
\hline$\beta$ - Lg & Bos d 5 & 4 & 10 & 18.3 & 5.3 & $\begin{array}{l}>90 \% \text { of cow milk allergic patients showed IgE binding in CRIE; }>90 \% \\
\text { showed IgE binding in ELISA to Bos d } 5 \text { and Bos d } 5 \text { peptides }\end{array}$ \\
\hline BSA & Bos d 6 & 0.4 & 1 & 66.3 & $4.9-5.1$ & $>90 \%$ of cow milk allergic patients showed IgE binding in CRIE \\
\hline immunoglobulin & Bos d 7 & 1 & 3 & 160 & & IgE binding of milk-allergic patients to IgE in CRIE \\
\hline casein fraction & & 30 & 80 & & & \\
\hline$\alpha \mathrm{S} 1$-casein & Bos d 9 & 15 & 29 & 23.6 & $4.9-5.0$ & $\begin{array}{l}57 \text { of } 58 \text { casein-sensitized milk-allergic children showed IgE binding in an } \\
\text { enzyme immunoassay }\end{array}$ \\
\hline$\alpha \mathrm{S} 2$-casein & Bos d 10 & 4 & 8 & 25.2 & $5.2-5.4$ & $\begin{array}{l}55 \text { of } 58 \text { casein-sensitized milk-allergic children showed IgE binding in an } \\
\text { enzyme immunoassay }\end{array}$ \\
\hline$\beta$-casein & Bos d 11 & 11 & 27 & 24 & $5.1-5.4$ & $\begin{array}{l}53 \text { of } 58 \text { casein-sensitized milk-allergic children showed IgE binding in an } \\
\text { enzyme immunoassay }\end{array}$ \\
\hline k-casein & Bos d 12 & 4 & 10 & 19 & $5.4-5.6$ & $\begin{array}{l}53 \text { of } 58 \text { casein-sensitized milk-allergic children showed IgE binding in an } \\
\text { enzyme immunoassay }\end{array}$ \\
\hline
\end{tabular}

${ }^{a}$ Adapted with permission from refs 10 and 21 and World Health Organization (WHO)/International Union of Immunological Societies (IUIS) Allergen Nomenclature (http://www.allergen.org).

safety, quality, and technical feasibility, will easily replace traditional pasteurization and sterilization methods for a wide range of food products. This change has, in fact, already started. $^{18}$ Currently, the effect of $\mathrm{OH}$ on food protein allergenicity is being questioned. ${ }^{19,20}$ Can electrical variables of $\mathrm{OH}$ impact different aspects of food allergenicity? The literature on this matter is scarce, but it is consensual that food processed by simultaneous thermal and electrical methods should be thoroughly investigated, once their impact should not be comparable to that of conventional heating processing methods. ${ }^{19,20}$ The purpose of this perspective is (i) to discuss the advances on the impact of the current food processing factors (e.g., time-temperature binomial) on allergenicity of milk proteins, (ii) to discuss the novel opportunities that electroheating technologies, i.e., $\mathrm{OH}$, may bring to this science field, and (iii) to prospect the challenges that need to be overcome to an accurate risk assessment of food allergenicity.

\section{INFLUENCE OF PROCESSING ON MILK PROTEIN ALLERGENICITY}

To have a clear understanding of how electroheating technologies influence CMPA, it is important to summarize the allergenic adverse reactions and pathways, briefly introducing the processing methods currently used in the food industry.

Allergic Reaction. An allergic reaction can be simply described as a process in which an allergen substance after priming the immune system for the first time, known as sensitization or sensitizing potential, will unchain a set of specific immune responses after a second contact. $^{21,22}$ According to the European Food Safety Authority (EFSA), ${ }^{23}$ food allergy is defined as an adverse health reaction caused by the immune system that generally but not exclusively is mediated by immunoglobulin class $\mathrm{E}$ antibodies ( $\mathrm{IgE}$ ). The IgE-mediated allergies may result in rapid, severe reactions associated with respiratory, cardiovascular, or cutaneous symptoms that ultimately can lead to a systemic collapse (anaphylaxis), while non-IgE-mediated immune responses can mainly cause subacute or chronic GI tract disorders. ${ }^{23}$
It is currently recognized that food processing can impact allergenicity in two distinguished ways: ${ }^{22}$ (i) by altering the ability of the allergen to sensitize the immune system to produce IgE or (ii) by changing the integrity of allergen epitopes recognized by $\operatorname{IgE}$ of the immune system. It is crucial to understand the effects that food processing may have on three-dimensional structures of allergens, particularly how it affects epitope integrity and recognition by IgE binding sites, but also to identify processing strategies that can avoid the sensitization step.

Milk Allergens. Allergens in milk are well-identified and associated with casein and whey protein fractions. Table 1 summarizes the most recognized cow milk protein allergens and their main characteristics. Despite no single protein has been identified as the most allergenic, as a result of the great difficulty in interpreting the variability of immune responses, it is considered that the most frequent allergens are related to the most abundant proteins in milk, as is the case of $\alpha_{\mathrm{S} 1}$-casein, $\beta$ lactoglobulin $(\beta-\mathrm{Lg})$, and $\alpha$-lactalbumin $(\alpha$-La), which are involved in severe allergy in childhood but also in adults. ${ }^{9,10}$ Then, these proteins are well-characterized, and for that reason, they are good candidates to be used as models for the evaluation of the effects of novel processing strategies on their sensitization and allergenicity potential. $\beta$-Lg presents particular relevance, once it is the most abundant cow's milk whey protein, and it is not present in human milk. However, other minor proteins present in trace amounts, such as bovine serum albumin (BSA) and lactoferrin, should not be completely overlooked, once they can present important allergenic activity. ${ }^{24}$

Milk Processing Methods. Cow milk and its derived ingredients and products are frequently subject to several kinds of processing that include several unit operations, such as homogenization, pasteurization, sterilization, enzymatic hydrolysis, fermentation, condensation, glycation, and drying. Any processing treatment leading to generation of minimal allergic components can be employed successfully for the commercial production of many niche products, especially infant milk powder, infant formula, and other baby foods. Therefore, discussion regarding the effects of processing 
techniques (thermal/non-thermal) becomes pertinent at present.

Among these operations, heating treatments are of utmost importance in affecting biochemical and functional properties of milk proteins, particularly the milk proteins that are less heat-stable, such as whey proteins. Heating pasteurization methods relying on low temperature long time (LTTL, $65^{\circ} \mathrm{C}$ for $30 \mathrm{~min}$ ), high temperature short time (HTST, 70-80 ${ }^{\circ} \mathrm{C}$ for $15-20 \mathrm{~s}$ ), and ultrahigh temperature (UHT, $130-140{ }^{\circ} \mathrm{C}$ in less than $1 \mathrm{~s}$ ) are prevalent in developed countries. $\beta$ - $\mathrm{Lg}$, which dominates the functional properties of the whey fraction, undergoes important structural and chemical changes during heating involving: (i) intramolecular transitions $(<60$ $\left.{ }^{\circ} \mathrm{C}\right)$, (ii) loss of secondary structure and onset of denaturation $\left(60-70{ }^{\circ} \mathrm{C}\right)$, (iii) reshuffling of intramolecular disulfide bonds, and (iv) intermolecular interactions that result in irreversible denaturation and the formation of protein aggregates ( $>80$ $\left.{ }^{\circ} \mathrm{C}\right)$. The kinetics of these cascade reactions and structural changes depend upon the protein type and physical and biochemical parameters, such as the protein concentration, ionic strength, $\mathrm{pH}$, and thermal load applied, i.e., heating temperature, holding time, heating rate, and heating method (direct or indirect). The influence of these parameters on milk protein denaturation has been extensively studied and reviewed for decades until now. ${ }^{25}$ It seems consensual that these alterations may change the antigenicity of whey proteins, ${ }^{11}$ but it is still inconclusive in which direction. Verhoeckx and co-workers ${ }^{22}$ concluded that pasteurization can increase allergenicity of milk (measured by $\operatorname{IgE}$ binding studies), while sterilization can reduce it by the combination of existing epitopes of both $\beta$ - $\operatorname{Lg}$ and $\alpha$-La with reducing sugars during the Maillard reaction. $\mathrm{Bu}$ et al. ${ }^{26}$ summarize that the antigenicity of $\alpha$-La and $\beta$ - $\mathrm{Lg}$ in whey protein isolate (WPI) evaluated by means of indirect competitive enzyme-linked immunosorbent assays (ELISA) can be controlled by the heating temperature and treatment time. These authors observed that antigenicity (antigen binding ability) of $\alpha$-La and $\beta$ - $\mathrm{Lg}$ can be increased with treatments ranging from 50 to $90{ }^{\circ} \mathrm{C}$ but significantly reduced when high-temperature regimes (i.e., between 90 and $120{ }^{\circ} \mathrm{C}$ ) are applied. The World Allergy Organization (WAO $)^{27}$ and EFSA documents highlight that, despite slight reductions of whey protein antigenicity upon heating, insignificant alterations in binding properties are reported with casein, which have a more linear, thermostable structure, thus maintaining its allergenic character. Interestingly, all of these works unveil a common aspect: protein aggregation. Protein aggregates formed during heating can have a crucial role on binding of specific IgE but also in sensitization. Figure 1 shows examples of different whey protein aggregate morphologies obtained upon thermal denaturation. In vivo and in vitro studies show that pasteurization can give rise to whey protein aggregates that can induce the first steps of allergic sensitization in intestinal mucosa, changing the path of antigen uptake from intestinal absorptive cells to Peyer's patches, which contain $\mathrm{M}$ cells. On the other hand, soluble milk proteins can trigger a rapid anaphylaxis response, once uptake across the small intestinal epithelium is not impaired. ${ }^{28}$ For instance, it was reported that rats treated with native $\beta$-Lg presented higher IgE levels than those treated with heat-denatured $\beta$ - $\mathrm{Lg}$ (enhancing a systemic allergic sensitization), whereas heat-denatured $\beta$ - $\mathrm{Lg}$ induced a chronic inflammatory response in the GI tract. ${ }^{29}$ The size of protein aggregates can strongly influence how denaturated $\beta$ -
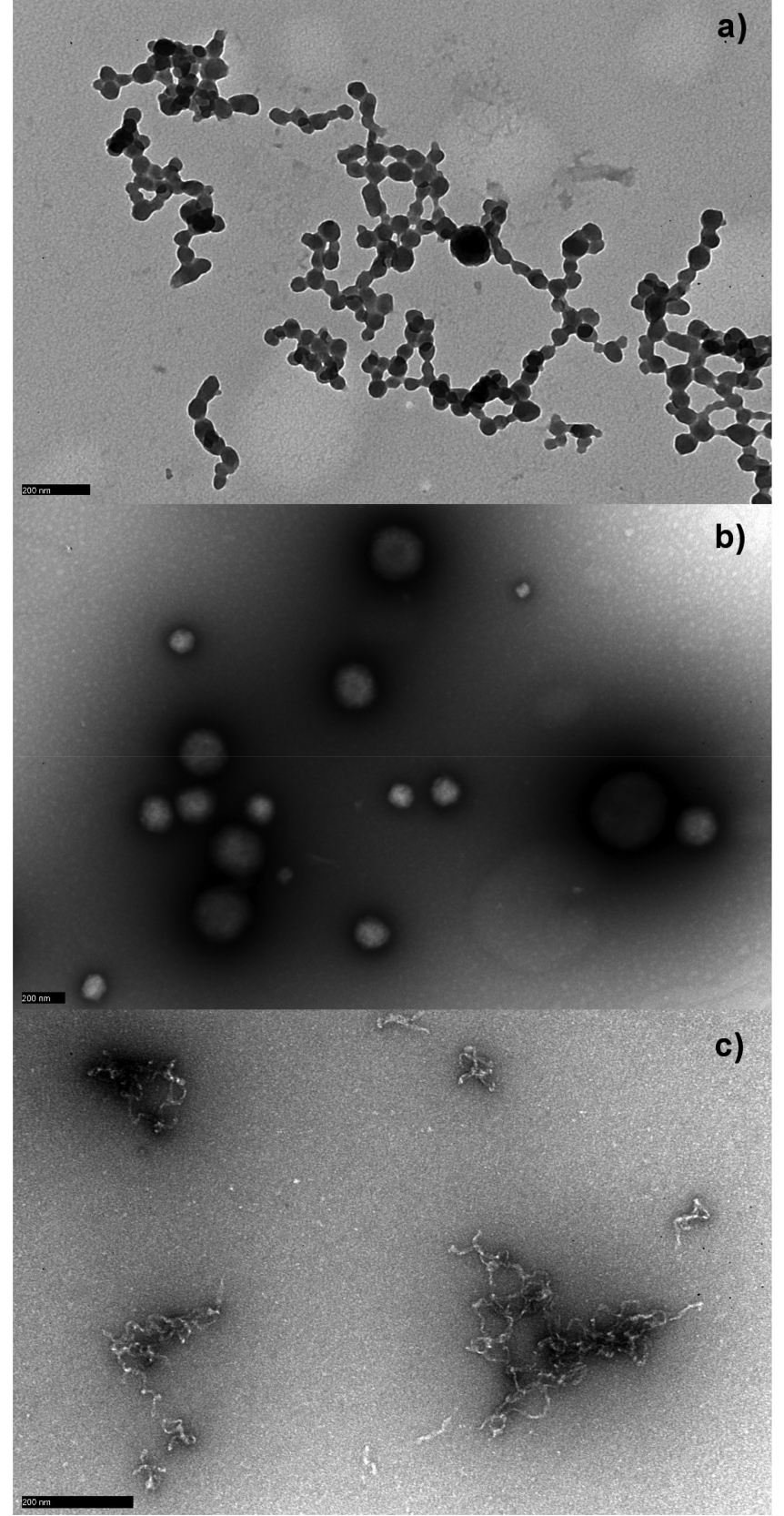

Figure 1. Transmission electron microscopy (TEM) micrographs of different morphologies of whey protein aggregates: (a) network of spherical aggregates of $\alpha$-La and lysozyme at $2 \mathrm{mg} / \mathrm{mL}$ (molar ratio of $0.546: 1)$ at $\mathrm{pH} 11$ after thermal heating at $75{ }^{\circ} \mathrm{C}$ for $15 \mathrm{~min}$, (b) spherical aggregates of $\beta$ - $\mathrm{Lg}$ at $\mathrm{pH} 6$ after thermal heating at $80^{\circ} \mathrm{C}$ for $10 \mathrm{~min}$, and c) fibrillar aggregates of $\beta$ - $\mathrm{Lg}$ at $3 \mathrm{mg} / \mathrm{mL}$ at $\mathrm{pH} 3$ after thermal heating at $90{ }^{\circ} \mathrm{C}$ for $5 \mathrm{~min}$. All scale bars correspond to a size of $200 \mathrm{~nm}$.

Lg protein is transported through epithelial cells; it was suggested that native $\beta$ - $\mathrm{Lg}$ is easily transported and less degraded by $M$ cells and Caco- 2 cell types when compared to protein aggregates. ${ }^{30}$ Macrophage cells in Peyer's patch can contribute to the degradation of protein aggregates.

Proteolysis, by either lactic acid bacteria fermentation or enzymatic hydrolysis, is recognized as the most effective method to reduce to a great extent the allergenicity of milk, once extensive hydrolysis can destroy allergenic epitopes, thus giving rise to hypoallergenic formulas. ${ }^{11,22}$ Still, these formulas 
are also known by having an unpleasant taste, which may reduce their acceptance from an organoleptic point of view. ${ }^{31}$ Other methods, such as glycation, which comprises conjugation with reducing sugars through the Maillard reaction, is somehow controversial, once it can be used to modulate the binding potential of specific IgE to food allergens. Extended denaturation and glycation can destroy existing $\beta$ - $\mathrm{Lg}$ epitopes, ${ }^{32}$ but newly formed protein agglomerates and advanced glycation end products (AGEs) may also play a role in food allergy that need to be fully understood. ${ }^{33}$ More recently, the combination of non-thermal processing methods, such as high hydrostatic pressure processing (HHP) with protein hydrolysis, appears to be an efficient strategy for producing hypoallergenic whey hydrolysates. ${ }^{11}$ Recently, in vitro studies have shown that the tertiary structure of $\beta$-Lg can be changed significantly under HPP, showing a potential to reduce allergenicity, which needs to be confirmed. ${ }^{34}$

\section{EFFECTS OF ELECTROHEATING ON ALLERGENICITY OF MILK PROTEINS}

Electrical-field-based processing has brought new insights toward important structural effects on biological entities (i.e., additional microbial inactivation through electroporation effects) and food macromolecules, approaching a broad commercial application. However, how can these processing strategies affect milk allergenicity? Thus far, the literature is scarce; however, some hypotheses may be advanced on the basis of knowledge about the technology fundamentals and what is recognized until now regarding its effects on milk protein allergens.

Electroheating Technologies. Electric field food processing is based on the concept of applying an external electric field to a food sample with a certain electrical conductivity that will act as a semiconductor, allowing for the passage of an electrical current. Dependent upon the intensity of the tension applied and treatment time scale, dissipation of volumetric heat inside the food occurs in accordance with the Joule effect. Once the generation of internal heat is a controllable side effect of electric field application, several electroheating processing strategies can be adopted to enhance heat generation (such as $\mathrm{OH}$ ) and electrical effects (minimizing the increase of the temperature) or both simultaneously. A good example of this versatility is the pulsed electric field (PEF) technology, a sister technology to $\mathrm{OH}$, where electric field pulses of high intensity (typically between 10 and $80 \mathrm{kV} / \mathrm{cm}$ ) are applied in less than seconds (usually between 1 and $10 \mu \mathrm{s}$ ), in practice "turning off" heat generation, thus keeping the temperature below denaturation levels. In contrast to $\mathrm{OH}, \mathrm{PEF}$ is considered a non-thermal technology that brings a new paradigm to organoleptic properties of foods as a result of reduced heating effects; however, because of this reason, it also shows limitations regarding the effective inactivation of more resistant organisms and molecules (in particular, spores and enzymes), which could imply a high economical cost. Until now, there is no research data available dealing with the assessment of the effect of PEF technology on allergenicity of milk proteins. ${ }^{35}$

Possibly because of a longer period of research when compared to PEF or HHP, OH is now establishing a solid foothold in the food industry. As a thermal technology, it can apply the prevalent heating binomials (assuring food safety) in a very rapid manner, both minimizing the negative aspects of the traditional thermal treatments (e.g., reducing overcooking) and bringing higher energetic efficiency (>90\%) with a relatively low capital cost. ${ }^{36}$ Extensive fundamental and applied research has been carried out regarding the application of $\mathrm{OH}$ to several food products, such as vegetables, fruits and fruit juice, meat, fish, and dairy products. ${ }^{19}$

$\mathrm{OH}$. Commercial applications of $\mathrm{OH}$ are based on the aseptic processing of particulate and protein-rich food products, relying mainly on pasteurization of liquid eggs and fruit pulps (multiphase composition), with processing capacities that can range from 3 to $9 \mathrm{t} / \mathrm{h} .{ }^{37} \mathrm{OH}$ application appears strongly associated with milk pasteurization, once it was its very first application. ${ }^{38}$ Since then, the effects of $\mathrm{OH}$ in biological (e.g., microbiological and enzyme inactivation) and chemical-physical aspects of milk protein (protein, lipid, and carbohydrate composition) have been extensively reviewed. Recently, $\mathrm{OH}$ was consistently considered a very promising technique for innovation in commercial dairy products, ${ }^{16,20}$ showing high potential for UHT processing of fragile dairy products, such as liquid infant formula. ${ }^{39}$

Effects of $\mathrm{OH}$ on Milk Allergens. It is expected that, in the near future, the market will offer a wide range of dairy products processed by $\mathrm{OH}$, but up to now, there is no published data about the influence of $\mathrm{OH}$ and its associated electric variables on allergenicity of milk proteins. ${ }^{19,20}$ In accordance with Jaeger et al., ${ }^{19}$ allergenic aspects of food processed by $\mathrm{OH}$ should be specifically evaluated and not inferred from the studies performed on food processed by the conventional thermal treatments. Moreover, extensive studies are fundamental to assess $\mathrm{OH}$ impacts on allergenicity, alone or in combination with other technologies, and tested using a variety of detection assays in different food matrices.

$\mathrm{OH}$ reduces the total thermal load in a given thermal treatment as a result of its direct and volumetric internal heating, the absence of hot surfaces, and natural ability to achieve rapidly high processing temperatures. This thermal treatment is then less aggressive for the structure of whey proteins, one of major allergens in milk, leading to a lower protein denaturation extent. However, the impact of this lower denaturation on allergenicity of these protein structures is still an open question. The balance between allergenicity alterations of the existing epitopes against a reduction in the formation of new allergenic structures (i.e., neoallergenic structures) upon this kind of heating is still unknown and needs to be investigated. Denaturation of whey proteins is generally assumed to be a two-step process consisting of (i) unfolding of the native protein and (ii) aggregation of unfolded protein molecules and irreversible denaturation. Under $\mathrm{OH}$, the native $\beta-\mathrm{Lg}$ structure is more preserved as a result of its faster heating rates; thus, the development of protein aggregates is reduced. ${ }^{40}$ This aspect can be of great relevance once denaturated $\beta$ - $\mathrm{Lg}$ can form complexes with casein micelles via $\mathrm{k}$-casein through sulfhydryl disulfide exchange reactions, with this being one of the major contributors to the changes in the casein micelle size during skim milk heating. The effect of $\mathrm{OH}$ during pasteurization of milk on the formation of heterogeneous aggregates between $\beta-\mathrm{Lg}, \alpha$-La, and casein micelles should be thoroughly characterized. Another important feature is that $\mathrm{OH}$ also appears as an emerging strategy for the inhibition or at least control of Maillard reactions as a result of reduction of overheating, ${ }^{41}$ which may eventually avoid the formation of neoallergenic species, such as AGEs. $\mathrm{OH}$ applications at sterilization temperature regimes $\left(>120{ }^{\circ} \mathrm{C}\right)$ are still less explored; for 


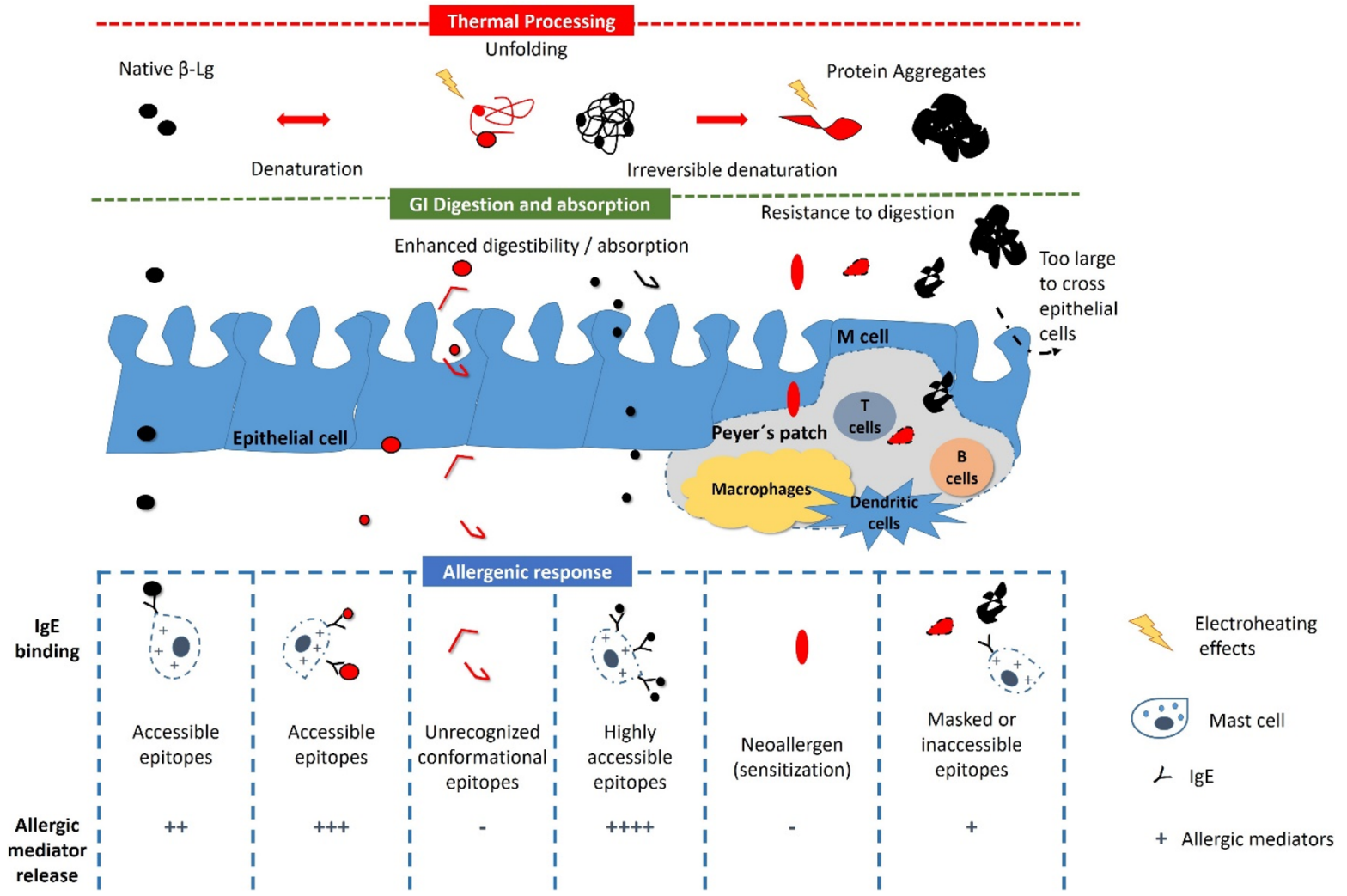

Figure 2. Schematic representation of the proposed influence of electroheating on protein denaturation and consequent effects on GI digestion and immunological IgE-mediated response.

instance, the effect of $\mathrm{OH}$ sterilization temperatures on caseins is still unknown.

Together with the thermal effects outlined before, the electrically caused changes of $\mathrm{OH}$ can also have a relevant impact on milk protein allergenicity. Recent studies emphasize the existence of non-thermal effects of moderate electric fields on whey protein denaturation kinetics and aggregation patterns. $\mathrm{OH}$ at low alternating electric fields (below $20 \mathrm{~V} /$ $\mathrm{cm}$ ) can change the morphology and functional aspects of the produced whey protein aggregates, and this may be linked to (i) conformational disturbances on the tertiary protein structure, (ii) reorientation of hydrophobic clusters occurring in the protein structure, or (iii) splitting of protein large aggregates. $^{40}$ All of these events can change sensitization potential, influence allergen epitope recognition, or in contrast, give rise to neoallergenic species. As outlined before, protein aggregates can change the path of allergic response via the GI tract, and this seems to be strictly dependent upon the resistance of these aggregates to GI digestion. ${ }^{42}$ It can be speculated that the major contributions that $\mathrm{OH}$ may bring to structure modification and immune reactivity of electroheated proteins may be linked to a fine-tune control of the heating process and with perturbations that the electrical variables may promote on the protein-protein interactions or in the development of complexes between proteins and other macromolecules, such as carbohydrates and lipids. Electroheating by changing protein denaturation pathways can give rise to higher levels of protein in its native form or in a partially unfolded state or even to new aggregated forms, thus influencing intestinal absorption and immunological responses. Figure 2 shows the influence that electroheating may exert on protein denaturation and inherent immunological outcomes.

\section{FUTURE PERSPECTIVES}

An accurate evaluation of the effects of heat processing on allergenicity and potential sensitization is a challenge, even more for novel or emergent technologies, such as electroheating technologies. It seems consensual that allergenicity of milk proteins can be altered by heating, but how it acts is still controversial. In the future, it will be crucial to establish a harmonized method for the risk assessment of protein allergenicity. This method should integrate not only advanced methods of protein structural characterization and traditional immunometric techniques, such as immunoblotting and ELISA, but also specific knowledge about GI digestion and subsequent interaction with the intestinal immune system. We believe that in vitro (e.g., using Caco-2 or HT-29 cell standardized models) and in vivo (e.g., using murine models) assessment and outcomes in the GI tract, from both protein potential immunological response and digestion and intestinal barrier properties, should be evaluated, thus offering an opportunity to correlate biological effects (e.g., allergic symptomatology) with protein allergen structural modifications imposed by food processing. This might be an additional important tool in allergenicity risk assessment motivated by electroheating processes. Any processing treatment leading to the generation of minimal allergic components will have a great impact on the dairy industry. However, the effect of food processing in the prevention of protein-related milk allergy will only be understood through a collaborative work at the scientific, technological, and applied levels, combining efforts of nutritionists, food scientists, and molecular biologists. Only with a consistent and concerted strategy of analysis will it be possible to obtain reliable conclusions and a better comparability between allergenicity studies in the future, 
including the contribution of the novel food processing technologies. Thermal and electrical singularities of $\mathrm{OH}$ can significantly change denaturation kinetics of labile proteins (such as whey proteins) and, consequently, their aggregation and interaction with other milk proteins, such as caseins. Novel insights brought by $\mathrm{OH}$ show that electrically induced changes affect the structure and stability of protein aggregates and complexes. These events can change how these aggregates are handled during GI digestion and absorbed in the intestinal mucosa. The influence of $\mathrm{OH}$ electrical variables, such as electric field, current density, and electrical frequency, on the protein structure and formed aggregates needs more fundamental knowledge and research. An innovative perspective of $\mathrm{OH}$ application may consist in the modulation of molecular unfolding and aggregation of whey protein allergens to reduce their capacity to elicit an allergic reaction or change the acquisition capacity of proteins to cause allergic sensitization. A combination of electric and thermal effects through an $\mathrm{OH}$ pasteurization/sterilization process may offer an opportunity for development of innovative hypoallergeniclike whey products of high sensorial and nutritional quality. However, it is still crucial for a clearer understanding of electroheating-induced effects on structural aspects of proteins and their interaction within a real food matrix, such as milk. $\mathrm{OH}$ processing should be designed alone or together with other currently used processing technologies (i.e., partial hydrolysis, fermentation, and HHP) to reduce the potential allergenicity of milk allergens or at least avoid the formation of neoallergenic species. In the light of the aforementioned standpoints and with dissemination of $\mathrm{OH}$ commercial applications, future research about the effects of this technology on allergenicity of milk proteins will be increasingly needed.

\section{AUTHOR INFORMATION}

\section{Corresponding Author}

*E-mail: avicente@deb.uminho.pt.

\section{ORCID $\odot$}

Ricardo N. Pereira: 0000-0003-1553-9693

Rui M. Rodrigues: 0000-0002-4416-0220

António A. Vicente: 0000-0003-3593-8878

\section{Funding}

This study was supported by the Portuguese Foundation for Science and Technology (FCT) under the scope of the strategic funding of UID/BIO/04469/2013 unit and COMPETE 2020 (POCI-01-0145-FEDER-006684) and BioTecNorte operation (NORTE-01-0145-FEDER-000004) funded by European Regional Development Fund under the scope of Norte2020, Programa Operacional Regional do Norte. Ricardo N. Pereira, Rui M. Rodrigues, Óscar L. Ramos, Ana C. Pinheiro, and Joana T. Martins gratefully acknowledge FCT for their financial grants with references SFRH/BPD/81887/2011, SFRH/BD/110723/2015, SFRH/BPD/80766/2011, SFRH/ $\mathrm{BPD} / 101181 / 2014$, and $\mathrm{SFRH} / \mathrm{BPD} / 89992 / 2012$, respectively.

Notes

The authors declare no competing financial interest.

\section{REFERENCES}

(1) Clerfeuille, E.; Maillot, M.; Verger, E. O.; Lluch, A.; Darmon, N.; Rolf-Pedersen, N. Dairy Products: How They Fit in Nutritionally Adequate Diets. J. Acad. Nutr. Diet. 2013, 113 (7), 950-956.
(2) Balthazar, C. F.; Silva, H. L. A.; Esmerino, E. A.; Rocha, R. S.; Moraes, J.; Carmo, M. A. V.; Azevedo, L.; Camps, I.; Abud, Y. K. D.; Sant'Anna, C.; Franco, R. M.; Freitas, M. Q.; Silva, M. C.; Raices, R. S. L.; Escher, G. B.; Granato, D.; Senaka Ranadheera, C.; Nazarro, F.; Cruz, A. G. The addition of inulin and Lactobacillus casei 01 in sheep milk ice cream. Food Chem. 2018, 246, 464-472.

(3) Dantas, A. B.; Jesus, V. F.; Silva, R.; Almada, C. N.; Esmerino, E. A.; Cappato, L. P.; Silva, M. C.; Raices, R. S.; Cavalcanti, R. N.; Carvalho, C. C.; Sant'Ana, A. S.; Bolini, H. M.; Freitas, M. Q.; Cruz, A. G. Manufacture of probiotic Minas Frescal cheese with Lactobacillus casei Zhang. J. Dairy Sci. 2016, 99 (1), 18-30.

(4) Ramos, O. L.; Pereira, R. N.; Martins, A.; Rodrigues, R.; Fucinos, C.; Teixeira, J. A.; Pastrana, L.; Malcata, F. X.; Vicente, A. A. Design of whey protein nanostructures for incorporation and release of nutraceutical compounds in food. Crit. Rev. Food Sci. Nutr. 2017, 57 (7), 1377-1393.

(5) Akal, C. Benefits of Whey Proteins on Human Health. In Dairy in Human Health and Disease Across the Lifespan; Watson, R. R., Collier, R. J., Preedy, V. R., Eds.; Academic Press: Cambridge, MA, 2017; Chapter 28, pp 363-372.

(6) Tunick, M. H. Whey Protein Production and Utilization: A Brief History. Whey Processing, Functionality and Health Benefits; WileyBlackwell: Hoboken, NJ, 2009; pp 1-13.

(7) Sanchón, J.; Fernández-Tomé, S.; Miralles, B.; HernándezLedesma, B.; Tomé, D.; Gaudichon, C.; Recio, I. Protein degradation and peptide release from milk proteins in human jejunum. Comparison with in vitro gastrointestinal simulation. Food Chem. 2018, 239, 486-494.

(8) Meyer, R.; Groetch, M.; Venter, C. When Should Infants with Cow's Milk Protein Allergy Use an Amino Acid Formula? A Practical Guide. J. Allergy Clin. Immunol. 2018, 6 (2), 383-399.

(9) Lam, H. Y.; Van Hoffen, E.; Michelsen, A.; Guikers, K.; Van Der Tas, C. H. W.; Bruijnzeel-Koomen, C. A. F. M.; Knulst, A. C. Cow's milk allergy in adults is rare but severe: Both casein and whey proteins are involved. Clin. Exp. Allergy 2008, 38 (6), 995-1002.

(10) Hochwallner, H.; Schulmeister, U.; Swoboda, I.; Spitzauer, S.; Valenta, R. Cow's milk allergy: From allergens to new forms of diagnosis, therapy and prevention. Methods 2014, 66 (1), 22-33.

(11) Bu, G.; Luo, Y.; Chen, F.; Liu, K.; Zhu, T. Milk processing as a tool to reduce cow's milk allergenicity: A mini-review. Dairy Sci. Technol. 2013, 93 (3), 211-223.

(12) Monteiro, S. H. M. C.; Silva, E. K.; Alvarenga, V. O.; Moraes, J.; Freitas, M. Q.; Silva, M. C.; Raices, R. S. L.; Sant'Ana, A. S.; Meireles, M. A. A.; Cruz, A. G. Effects of ultrasound energy density on the nonthermal pasteurization of chocolate milk beverage. Ultrason. Sonochem. 2018, 42, 1-10.

(13) Amaral, G. V.; Silva, E. K.; Costa, A. L. R.; Alvarenga, V. O.; Cavalcanti, R. N.; Esmerino, E. A.; Guimarães, J. T.; Freitas, M. Q.; Sant'Ana, A. S.; Cunha, R. L.; Moraes, J.; Silva, M. C.; Meireles, M. A. A.; Cruz, A. G. Whey-grape juice drink processed by supercritical carbon dioxide technology: Physical properties and sensory acceptance. LWT 2018, 92, 80-86.

(14) Pereira, R. N.; Vicente, A. A. Novel Technologies for Milk Processing. In Engineering Aspects of Milk and Dairy Products; Coimbra, J. S. R., Teixeira, J. A., Eds.; CRC Press: Boca Raton, FL, 2009.

(15) Cappato, L. P.; Ferreira, M. V. S.; Moraes, J.; Pires, R. P. S.; Rocha, R. S.; Silva, R.; Neto, R. P. C.; Tavares, M. I. B.; Freitas, M. Q.; Rodrigues, F. N.; Calado, V. M. A.; Raices, R. S. L.; Silva, M. C.; Cruz, A. G. Whey acerola-flavoured drink submitted Ohmic Heating: Bioactive compounds, antioxidant capacity, thermal behavior, water mobility, fatty acid profile and volatile compounds. Food Chem. 2018, 263, 81-88.

(16) Pereira, R. N.; Teixeira, J. A.; Vicente, A. A.; Cappato, L. P.; da Silva Ferreira, M. V.; da Silva Rocha, R.; da Cruz, A. G. Ohmic heating for the dairy industry: A potential technology to develop probiotic dairy foods in association with modifications of whey protein structure. Curr. Opin. Food Sci. 2018, 22, 95-101. 
(17) Costa, N. R.; Cappato, L. P.; Ferreira, M. V. S.; Pires, R. P. S.; Moraes, J.; Esmerino, E. A.; Silva, R.; Neto, R. P. C.; Tavares, M. I. B.; Freitas, M. Q.; Silveira, R. N., Jr.; Rodrigues, F. N.; Bisaggio, R. C.; Cavalcanti, R. N.; Raices, R. S. L.; Silva, M. C.; Cruz, A. G. Ohmic Heating: A potential technology for sweet whey processing. Food Res. Int. 2018, 106, 771-779.

(18) Tucker, G. Commercially successful applications. In Ohmic Heating in Food Processing-Electro-technologies for Food Processing Series; Ramaswamy, H. S., Marcotte, M., Sastry, S., Abdelrahim, K., Eds.; CRC Press: Boca Raton, FL, 2014.

(19) Jaeger, H.; Roth, A.; Toepfl, S.; Holzhauser, T.; Engel, K.-H.; Knorr, D.; Vogel, R. F.; Bandick, N.; Kulling, S.; Heinz, V.; Steinberg, $\mathrm{P}$. Opinion on the use of ohmic heating for the treatment of foods. Trends Food Sci. Technol. 2016, 55, 84-97.

(20) Cappato, L. P.; Ferreira, M. V. S.; Guimaraes, J. T.; Portela, J. B.; Costa, A. L. R.; Freitas, M. Q.; Cunha, R. L.; Oliveira, C. A. F.; Mercali, G. D.; Marzack, L. D. F.; Cruz, A. G. Ohmic heating in dairy processing: Relevant aspects for safety and quality. Trends Food Sci. Technol. 2017, 62, 104-112.

(21) Matsuo, H.; Yokooji, T.; Taogoshi, T. Common food allergens and their IgE-binding epitopes. Allergol. Int. 2015, 64 (4), 332-343.

(22) Verhoeckx, K. C. M.; Vissers, Y. M.; Baumert, J. L.; Faludi, R.; Feys, M.; Flanagan, S.; Herouet-Guicheney, C.; Holzhauser, T.; Shimojo, R.; van der Bolt, N.; Wichers, H.; Kimber, I. Food processing and allergenicity. Food Chem. Toxicol. 2015, 80, 223-240.

(23) European Food Safety Authority (EFSA).. Scientific opinion on the evaluation of allergenic foods and food ingredients for labelling purposes. EFSA J. 2014, 12 (11), 3894.

(24) Negaoui, H.; El Mecherfi, K. E.; Tadjer, S. A.; Grar, H.; Kheroua, O.; Saidi, D. Bovine lactoferrin allergenicity as studied in murine model of allergy. Food Agric. Immunol. 2016, 27 (5), 711-723. (25) Loveday, S. M. $\beta$-Lactoglobulin heat denaturation: A critical assessment of kinetic modelling. Int. Dairy J. 2016, 52, 92-100.

(26) Bu, G.; Luo, Y.; Zheng, Z.; Zheng, H. Effect of heat treatment on the antigenicity of bovine $\alpha$-lactalbumin and $\beta$-lactoglobulin in whey protein isolate. Food Agric. Immunol. 2009, 20 (3), 195-206.

(27) World Allergy Organization (WAO).. Diagnosis and Rationale for Action against Cow's Milk Allergy (DRACMA) Guidelines. Pediatr. Allergy Immunol. 2010, 21 (s21), 1-125.

(28) Roth-Walter, F.; Berin, M. C.; Arnaboldi, P.; Escalante, C. R.; Dahan, S.; Rauch, J.; Jensen-Jarolim, E.; Mayer, L. Pasteurization of milk proteins promotes allergic sensitization by enhancing uptake through Peyer's patches. Allergy 2008, 63 (7), 882-890.

(29) Rytkonen, J.; Karttunen, T. J.; Karttunen, R.; Valkonen, K. H.; Jenmalm, M. C.; Alatossava, T.; Bjorksten, B.; Kokkonen, J. Effect of heat denaturation on $\beta$-lactoglobulin-induced gastrointestinal sensitization in rats: Denatured $\beta \mathrm{LG}$ induces a more intensive local immunologic response than native $\beta$ LG. Pediatr. Allergy Immunol. 2002, 13 (4), 269-77.

(30) Rytkonen, J.; Valkonen, K. H.; Virtanen, V.; Foxwell, R. A.; Kyd, J. M.; Cripps, A. W.; Karttunen, T. J. Enterocyte and M-cell transport of native and heat-denatured bovine $\beta$-lactoglobulin: Significance of heat denaturation. J. Agric. Food Chem. 2006, 54 (4), $1500-7$.

(31) Miraglia Del Giudice, M.; D’Auria, E.; Peroni, D.; Palazzo, S.; Radaelli, G.; Comberiati, P.; Galdo, F.; Maiello, N.; Riva, E. Flavor, relative palatability and components of cow's milk hydrolysed formulas and amino acid-based formula. Ital. J. Pediatr. 2015, 41, 42. (32) Taheri-Kafrani, A.; Gaudin, J.-C.; Rabesona, H.; Nioi, C.; Agarwal, D.; Drouet, M.; Chobert, J.-M.; Bordbar, A.-K.; Haertle, T. Effects of Heating and Glycation of $\beta$-Lactoglobulin on Its Recognition by IgE of Sera from Cow Milk Allergy Patients. J. Agric. Food Chem. 2009, 57 (11), 4974-4982.

(33) Teodorowicz, M.; van Neerven, J.; Savelkoul, H. Food Processing: The Influence of the Maillard Reaction on Immunogenicity and Allergenicity of Food Proteins. Nutrients 2017, 9 (8), 835.

(34) Meng, X.; Bai, Y.; Gao, J.; Li, X.; Chen, H. Effects of high hydrostatic pressure on the structure and potential allergenicity of the major allergen bovine $\beta$-lactoglobulin. Food Chem. 2017, 219, 290296.

(35) Chizoba Ekezie, F.-G.; Cheng, J.-H.; Sun, D.-W. Effects of nonthermal food processing technologies on food allergens: A review of recent research advances. Trends Food Sci. Technol. 2018, 74, 1225.

(36) Sastry, S. K.; Heskitt, B. F.; Sarang, S. S.; Somavat, R.; Ayotte, K. Why Ohmic Heating? Advatanges, Applications, Technology, and Limitations. In Ohmic Heating in Food Processing-Electro-technologies for Food Processing Series; Ramaswamy, H. S., Marcotte, M., Sastry, S., Abdelrahim, K., Eds.; CRC Press: Boca Raton, FL, 2014.

(37) Varghese, K. S.; Pandey, M. C.; Radhakrishna, K.; Bawa, A. S. Technology, applications and modelling of ohmic heating: A review. J. Food Sci. Technol. 2014, 51 (10), 2304-2317.

(38) Anderson, A. K.; Finkelstein, R. A Study of the Electro-Pure Process of Treating Milk. J. Dairy Sci. 1919, 2 (5), 374-406.

(39) Roux, S.; Courel, M.; Birlouez-Aragon, I.; Municino, F.; Massa, M.; Pain, J.-P. Comparative thermal impact of two UHT technologies, continuous ohmic heating and direct steam injection, on the nutritional properties of liquid infant formula. J. Food Eng. 2016, $179,36-43$.

(40) Pereira, R. N.; Rodrigues, R. M.; Ramos, Ó. L.; Xavier Malcata, F.; Teixeira, J. A.; Vicente, A. A. Production of Whey Protein-Based Aggregates Under Ohmic Heating. Food Bioprocess Technol. 2016, 9 (4), 576-587.

(41) Lund, M. N.; Ray, C. A. Control of Maillard Reactions in Foods: Strategies and Chemical Mechanisms. J. Agric. Food Chem. 2017, 65 (23), 4537-4552.

(42) Pekar, J.; Ret, D.; Untersmayr, E. Stability of allergens. Mol. Immunol. 2018, 100, 14-20. 